\title{
Stabilization of IMPORTANT Tree NomenClature
}

The following report was filed by a special committee of the Society of American Foresters on Tree Names and was approved by the membership and Council of the Society.

Particular attention is drawn to Item 7 which recommends restoring and legalizing the name Pseudotsuga taxifolia.

(1) The need, in behalf of horticulturists, agronomists, foresters, physiologists, biochemists, pathologists and other biological workers, for a measure of relief from an unsettled nomenclature, has been set forth with great clarity and emphasis by Dr. Wendell H. Camp (now heard of the Department of Botany, University of Connecticut, Storrs, Conn., and a former president of the American Society of Plant Taxonomists) in his article "Codes, Taxonomic Coding, and Types". [Taxonomic Index 17(4,5); 45-48. Sep.-Oct., 1954]

(2) As a committee of the Society of American Foresters, we welcome the opportunity thus afforded foresters to contribute to a discussion of this problem aad to help, if possible, in some reasonable solution.

(3) Article 4 of the International Code of Botanical Nomenclature (Utrecht, 1952) states that the first essential point in nomenclature is "To aim at fixity of names." We are in hearty agreement with such an aim, and recommend renewed attention to that aim on the part of future framers of the Code.

(4) We unanimously recommend to the Society that it endorse the principle embodied in the article by Dr. Elbert L. Little, Jr., "Rejection of Obscure Plant Names Unaccepted within a Century." [Phytologia 3(3): 87-89. July, 1949] under which the priority rule (Article 16 of the Code) could be modified to outlaw changes due to the discovery of an obscure name a century or more old. Some members of the committee, however, think this period could be reduced, say, to 50,25 or even 10 years. Incidentally, such a revision of the priority rule would be in harmony with Article C. 12 of the "Proposed International Code of Nomenclature for Cultivated Plants" published as Appendix III of the International Code of Botanical Nomenclature.

(5) The International Botanical Congress at Amsterdam in 1935 appointed "A Special Committee for Nomenclature of Economic Plants," the purpose of which was to prepare a sort of check list of such plants, primarily for nontaxonomists. That list was never completed. Our committee, with one dissenting vote, suggest that our Society recommend reappointment of such a committee for economic plant nomenclature, provided suitable personnel can be obtained.

(6) The Committee membership divides 50-50 on the desirability of lists of nomina specifica conservanda and nomina specifica dejicienda. In view of what has happened at previous international botanical congresses it realizes the latter has a much better chance of adoption than the former. If we can get a modification of the priority rule [as indicated under "(4)" above] or a kind of standard economic plant list [as indicated under "(5)" above] such lists of conserved or rejected specific names might not be needed to obtain the relief desired. 
(7) The committee unanimously recommends that, by one or more of the methods indicated above, use of the scientific name Pseudotsuga taxifolia, the most important timber tree of the United States, if not in the world, be legalized. By the same token, but with one dissenting vote, your committee also recommends effort to legalize the following scientific names of two important American trees, Sequoia gigantea and Betula lutea, and agreement to accept Populus balsamifera (vice $P$. tacamahacca) for balsam poplar and Quercus rubra (vice $Q$. borealis) for northern red oak, the latter two names in question because of typification problems.

The above was respectfully submitted by: Henry I. Baldwin, Fox Research Forest, Hillsboro, New Hampshire; Keith W. Dorman, Southeastern Forest Experiment Station, Dry Branch, Georgia; John W. Duffield, Industrial Forestry Association, Portland 5, Oregon; Philip G. Haddock, University of British Columbia, Faculty of Forestry, Vancouver 8, B.C., Canada; Elbert L. Little, Jr., U.S. Forest Service, Washington 25, D.C.; and William A. Dayton, Chairman, U.S. Forest Service, Washington 25, D.C.

\section{HERMAN ALBERT SIEVERS}

Foresters, not only of this continent but from the European Countries, will mourn the loss of Herman Albert Sievers.

His influence for the extension of the practice of forestry has been felt in Canada from the time of his arrival here from Germany some time during the year 1928 until his death on November 25, 1955.

Herman was born at Brunswick, Germany, in the year 1906. After attending Common School and High School in Brunswick, he entered the Hildesheim Forestry School and garduated from there in 1928. Upon graduation he left for Canada where he has been employed in various fields of forestry until his death. He was employed as a Forester with the Casco Bay Timber Limited in Newcastle, N.B., with the Manitoba Pulp and Paper Company of Kenora, Ontario and also with the Marathon Corporation of Canada, Port Arthur, Ontario. The last position he held was with the Mariana Timber Limited of Baddeck, Nova Scotia where he held the position of Operation Manager.

For many years he had been an active member of the C.I.F. He was also a member of the American Society of Photogrammetry, the Canadian Pulp and Paper Association and the American Society of Military Engineers.

He took an active part in community affairs and was a friend to all who knew him. His hobbies were hunting and fishing. Herman's ability and experience placed him at the top of his profession. His sterling character, sound judgment, keen interest and good humor made him a welcomed and outstanding figure in any gathering, be it in the forest, around the camp fire or in any professional gathering.

He had the liking and respect of all whether a scaler, lumberjack, forester or company executive.

His sudden passing was keenly felt by all who knew him. To his widow, Giesle, and his son, Hans, the Institute and his many friends extend their deepest sympathy. 